\title{
Are Net Discount Ratios Stationary?: The Implications For Present Value Calculations
}

\author{
Joseph H. Haslag \\ Michael Nieswiadomy \\ D. J. Slottje
}

\begin{abstract}
This article analyzes the relationship between real interest rates and real growth rates in wages. The stationarity of these time series has been discussed in the literature. However, since the net discount ratio, $\left(1+g_{1}\right) /\left(1+r_{t}\right)$, is a nonlinear transformation, it is not necessarily stationary even if the interest rate and growth rate in wages series are each stationary. On the other hand, the net discount ratio may be stationary even if the interest rate and growth rate series are both non- stationary. The significant finding of this article is that this ratio is stationary. This conclusion appears robust since it holds for at least four different Treasury securities analyzed: three month, six month, one year, and three year. Therefore, a real net discount ratio, $\left(1+g_{t}\right) /\left(1+r_{t}\right)$, can be used with confidence in constructing present value forecasts of expected earnings.
\end{abstract}

Estimating the present value of future lost earnings is a complicated process. Some of the topics of recent research include methods of analyzing expected earnings (Becker and Alter, 1987), the age-earnings life cycle (Lane and Glennon, 1985; Lambrinos and Harmon, 1989), employee benefits (Nieswiadomy and Slottje, 1988), disability effects (Nieswiadomy and Silberberg, 1988), and the impact of state and federal taxes (Vernon, 1985). However, the determination of the correct growth rate in wages and the discount rate has received the most attention.

The purpose of this article is to explore the relationship between interest rates and growth rates by testing for stationarity of the net discount ratio. ${ }^{1}$ The next section discusses methods used to calculate the discount rate and growth rate. Then, unit root tests on the real growth rate in real wages, several real interest rates, and several real net discount ratios are discussed. The

Joseph H. Haslag is Senior Economist at the Federal Reserve Bank of Dallas and Visiting Assistant Professor of Economics at Southern Methodist University. Michael L. Nieswiadomy is Associate Professor of Economics at the University of North Texas. Daniel J. Slottje is Associate Professor of Economics at Southern Methodist University.

The authors would like to thank an anonymous referee for helpful comments.

${ }^{1}$ The other factors such as tax rates and age earnings profiles wich influence specific present value calculations are not analyzed int his article. They do not significatly affect the conclusions. 
nonlinear transformation that yields the net discount ratio also is discussed. Even if the growth rate of real wages and real interest rates are stationary, this finding would not imply that the net discount ratio is stationary.

\section{Past Approaches}

Although researchers disagree on the proper approach to determining the growth rate and discount rate, they generally agree on the use of historical data. However, several researchers have suggested bypassing the entire issue by using the total offset method (also referred to as the Alaska Method), whereby the growth rate effectively offsets the discount rate (Franz, 1978; Schilling, 1985). This method, however, makes the implicit assumption that these series are equal and their relationship is stable. Other researchers argue that growth and discount rates must be explicitly analyzed, but disagree over three main points. First, should growth and discount rates be analyzed independently (Laber, 1977)? Second, what is the appropriate type and term of the security used for the discount rate (Harris, 1983; Carpenter et al., 1986; Jones, 1985; Hickman, 1977; Bell and Taub, 1977; and Edwards, 1975)? Third, which industrial sector's wage should be used (Lane and Glennon, 1985; and Anderson and Roberts, 1989)?

Considerable variance in opinions surround the dependence of growth rates and discount rates. Several studies have found that the relationship is erratic. Leuthold (1981), using data between 1793 and 1979, concludes that the relationship between inflation and interest rates is not stable. Hosek (1982) argues that nominal wage rates and nominal interest rates are nonstationary time series. Schilling (1985), using historical data from 1900 through 1982, finds that the Alaska Method is the best of several methods, although none of the methods performs very well. In contrast, several studies found a stable relationship between growth rates and discount rates (Lambrinos, 1985; Anderson and Roberts, 1989; and Bryan and Linke, 1988).

\section{Stationarity Issues for Wages and Interest Rates}

A time-series is said to be stationary if the generating function for the series does not itself change through time (Granger, 1989, p. 66). Although serious problems can arise when non-stationary data are used, stationarity of the net discount ratio has received little attention. Engle and Granger (1987) show that if two series share a common relationship with time, the estimated correlation is potentially spurious. ${ }^{2}$

Two studies (Hosek, 1982; and Lambrinos, 1985) have explicitly examined the issue of stationarity of the growth rate and the discount rate. While it should be noted that these studies (as well as others) have made a significant

\footnotetext{
${ }^{2}$ Spurious correlation, however, is not problematic when the two series are co-integrated. Because a linear combination of the two series is stationary, (i.e., not a polynomical function of time), the inferences about the correlation coefficient are valid. See Pagan and Wickens (1989) for a detailed, intuitive discussion of integrated time series and co-integration.
} 
contribution to this literature, the analysis should be extended further, because the ultimate reason for analyzing the stationarity of these time series is to determine if the nonlinear expression, $\left(1+g_{t}\right) /\left(1+r_{t}\right),{ }^{3}$ is itself a stationary series, where " $r$ " stands for the real interest rate and " $g$ " stands for the growth rate in real wages. As Hallman and Granger (1989) have shown, non-linear transformations applied to non-stationary time series can yield stationary series, and vice-versa. Consequently, using stationary series such as $r_{t}$ and $g_{t}$, if they are found to be stationary, does not imply that the net discount ratio, $\left(1+g_{t}\right) /\left(1+r_{t}\right)$, is stationary.

To test for stationarity, it is necessary to determine the order of integration of the time-series being considered. If the order is equal to zero, the series is stationary. If, on the other hand, the series is integrated of order d (denoted $I(d)$ ), where $d$ is some positive integer, differencing of the series $d$ times is needed to yield a stationary series. ${ }^{4}$ Univariate analysis (unit-root testing) is conducted to determine the order of integration. For this study, the authors analyze the average hourly wage in the private nonagricultural sector (deflated by the CPI) and the real interest rate on different Treasury securities. To test for the presence of unit roots the following augmented Dickey-Fuller (1979) specification is adopted:

$$
\Delta \mathrm{X}_{\mathrm{t}}=\alpha+\beta \mathrm{X}_{\mathrm{t}-1}+\sum_{\mathrm{j}=1}^{4} \delta_{\mathrm{j}} \Delta \mathrm{X}_{\mathrm{t}-\mathrm{j}}
$$

The presence or absence of a unit root depends on the value of the coefficient of $\mathrm{X}_{\mathrm{t}-1}, \beta$. If the estimated coefficient is not statistically less than zero, $\mathrm{x}_{\mathrm{t}}$ has (at least) one unit root, and thus, the evidence suggests that the variable is not stationary. The test statistic is of the form of the student's $t$ for $\beta$, but the distribution of the test statistic is non-normal, asymptotically. From this distribution (see Fuller, 1976), the probability that the t-statistic is less than -2.88 (i.e., the probability of a Type-I error) is 5 percent.

\section{Unit-Root Tests for Stationarity}

The data are monthly and are available for the period from 1964:1 through 1989:4. 5 To calculate the ex post real return, the following expression was used: $r=[(1+i) /(1+\pi)]-1$, where $i$ is the nominal interest rate and $\pi$ is the inflation rate (measured as the annual rate of change in the CPI) that existed until that security matured. ${ }^{6}$ The model imposes the condition of rational expectations, i.e., expected inflation equals actual inflation. ${ }^{7}$

\footnotetext{
${ }^{3}$ This ratio is also sometimes written as $1 /\left(1+k_{l}\right)$, where $k_{t}$ is referred to as the net discount rate (e.g., see Anderson and Roberts, 1989).

${ }^{4}$ Note that $\mathrm{d}$ also corresponds to the number of unit roots in the time series.

${ }^{5}$ Monthly changes in hourly wage rates were first available in 1964.

${ }^{6}$ For example, the nominal return that was registered (on average) for three month bills in January, divided by the inflation rate over the period January to April, minus one, yields the ex post real return.

${ }^{7}$ The authors are grateful to an anonymous referee for suggesting this specification of the real rate. In an earlier version of the article, the authors followed Mishkin's (1988) appraoch of caluclating the ex post real rate, $\mathrm{r}=\mathrm{i}-\pi^{\mathrm{e}}$, where $\pi^{\mathrm{e}}=\pi$. This specification leaves off the
} 
Equation (1) is estimated using levels of the time series of interest rates and the log of real wages. ${ }^{8}$ Four different Treasury securities are analyzed: three month, six month, one year, and three year. As Table 1 indicates, the estimated coefficients on the lagged value of all of the Treasury securities are negative. Similarly, the coefficient on the lagged value of the (log of) real average hourly earnings is negative. ${ }^{9}$ In all of the cases, however, the $\mathrm{t}$-statistics, are larger than -2.32 . Since the 5 percent critical value is -2.88 , the evidence is consistent with the levels of average hourly earnings and real interest rates having a unit-root, i.e., each of the series are nonstationary. This evidence does not corroborate Lambrinos' (1985) conclusion (based on correlograms) that real interest rates are stationary.

\section{Table 1}

Unit-Root Test for Real Interest Rates and Real Wages, 1964:1 - 1989:4

$$
\begin{aligned}
\text { Models: (1) } \Delta \mathrm{X}_{\mathrm{t}}=\alpha+\beta \mathrm{X}_{\mathrm{t}-1}+\sum_{\mathrm{j}=1}^{4} \delta_{\mathrm{j}} \Delta \mathrm{X}_{\mathrm{t}-\mathrm{j}} \\
\text { (2)a } \Delta \mathrm{X}_{\mathrm{t}}=\alpha+\beta \mathrm{X}_{\mathrm{t}-1}+\sum_{\mathrm{j}=1}^{4} \delta_{\mathrm{j}} \Delta \mathrm{X}_{\mathrm{t}-\mathrm{j}}+\gamma \mathrm{t}
\end{aligned}
$$

\begin{tabular}{|c|c|c|c|c|}
\hline \multirow[b]{2}{*}{ Variable } & \multicolumn{2}{|c|}{$\begin{array}{c}\text { t-statistic on lag } \\
\text { variable, } x_{t-1}\end{array}$} & \multicolumn{2}{|c|}{$\begin{array}{c}\text { F-statistic on lag variable, } \\
x_{1-1} \text {, and time, } t\end{array}$} \\
\hline & Level & Change & Level & Change \\
\hline 3-month rate & -2.22 & $-9.65^{*}$ & 3.48 & $45.60 *$ \\
\hline 6-month rate & -2.32 & $-7.60^{*}$ & 3.73 & $28.81^{*}$ \\
\hline 1-year rate & -1.91 & $-6.03^{*}$ & 2.77 & $18.16^{*}$ \\
\hline 3 -year rate & -1.49 & $-5.55^{*}$ & 1.43 & $15.38^{*}$ \\
\hline log of wage rate & -0.81 & $-5.33^{*, \mathrm{~b}}$ & 4.42 & $15.59^{*}, \mathrm{~b}$ \\
\hline
\end{tabular}

\footnotetext{
* denotes significance at the 5 percent level.
}

The 5 percent critical value for the t-ratio is -2.88 .

The 5 percent critical value for the F-ratio is 6.34 .

aNote in model (2) that $t$ represents the time trend variable.

bIn essence the growth rate in real wages is being examined since a change in the log of real wages is being used.

In the second test, a time trend variable is included in the regression as shown in Equation (2).

$$
\Delta \mathrm{X}_{\mathrm{t}}=\alpha+\beta \mathrm{X}_{\mathrm{t}-1}+\sum_{\mathrm{j}=1}^{+} \delta_{\mathrm{j}} \Delta \mathrm{X}_{\mathrm{t}-\mathrm{j}}+\gamma \mathrm{t}
$$

interaction term, $\mathrm{r} \pi^{\mathrm{e}}$. Using the Mishkin (1988) approach does not materially alter the results presented in this article.

${ }^{8}$ It should be noted that the level of real interest rates is $r$. However, the real wage rate is converted to percentage changes to yield $\mathrm{g}$, the growth rate, when it is differenced because the log of wages is used.

${ }^{9}$ The unit-root test was also conducted for the level of the real wage. As one might expect, with a unit root in the log-level of the series, the evidence indicated that a unit-root was present in the real wage level as well. 
The null hypothesis is that the coefficients on the lagged level of the series and on the time variable are jointly equal to zero. The intuition behind this test is that the series may be made up of both deterministic and stochastic trend components. ${ }^{10}$ The F-statistic for this null hypothesis will exceed its critical value if either the deterministic trend explains a large portion of the time series (which is reflected in the coefficient on the time variable being different from zero) or the stochastic trend is small (which results in the coefficient on the lagged value being significantly less than zero). The results of this second test are consistent with those in the first test; that is, under the null hypothesis, the F-statistics are all less than 3.73 for the real interest rates. The F-statistic is 4.42 for average hourly earnings. In all cases, since the values of the F-statistics are well below the critical value of 6.34 , the null hypothesis is not rejected. Thus, even with a trend adjustment, the evidence suggests that interest rate and level of wages series are not stationary.

The next step is to determine whether a second unit root is present in the data. If so, then the first differences are non-stationary. Equation (1) is also estimated with first differences of the various real interest rates ( $r$ ) and the growth rate $(\mathrm{g})$ of real average hourly earnings. The results of these estimations are also presented in Table 1 (in the second column). Under the null hypothesis that the coefficient on the lagged first difference of the Treasury interest rate is less than zero, the t-statistics range from -5.55 to -9.65. In each case the evidence suggests that the first difference of these real interest rate series are stationary. This result indicates that the real Treasury rate series must be first-differenced before any forecasting is done using these individual series. The growth rate of the real average hourly earning series is stationary, as indicated by a t-statistic of -5.33 . Furthermore, when a time trend is included in the models, the conclusions based on the F-statistics in the last column of Table 1 are congruent with the unit-root tests in equation (1): the first-differenced real interest rate series are stationary, and the growth rate is stationary. The present evidence on the stationarity of the growth rate of wages is consistent with Lambrinos' (1985).

In short, the evidence is consistent with the hypothesis that real interest rates are not stationary, but that the growth rate of real average hourly earnings is stationary. This result could present serious problems for forecasting the present value of expected future earnings since only one of the series is stationary. However, as noted above, it is possible that the $\left(1+g_{t}\right) /\left(1+r_{t}\right)$ series is stationary even though the real interest rate is not stationary since this series is a non-linear transformation of the $r_{t}$ and $g_{t}$ series.

Unit root tests on $\left(1+g_{t}\right) /\left(1+r_{t}\right)$, the net discount ratio, are presented in Table 2. These tests were conducted in a similar fashion to the ones described in Table 1. Four different net discount ratios are constructed, one for each of the different real interest rates under consideration, while the same growth rate in real wages is used each time. In each interest rate case, that t-statistic

\footnotetext{
${ }^{10}$ See Stock and Watson (1988) for a description of the breakdown of a series into its deterministic and stochastic trend components.
} 
calculated under the null hypothesis of unit root, is less than -2.88 , indicating that the null hypothesis is rejected. The evidence is consistent with the hypothesis that the discount ratio is stationary.

Table 2

Unit-Root Test for the Net Discount Ratio 1964:1 - 1989:4

$$
\mathrm{x}_{\mathrm{t}}=\left(1+\mathrm{g}_{\mathrm{t}}\right) /\left(1+\mathrm{r}_{\mathrm{t}}\right)=1 /\left(1+\mathrm{k}_{\mathrm{t}}\right)
$$

Models: (1) $\Delta \mathrm{X}_{\mathrm{t}}=\alpha+\beta \mathrm{X}_{\mathrm{t}-1}+\sum_{\mathrm{j}=1}^{4} \delta_{\mathrm{j}} \Delta \mathrm{X}_{\mathrm{t}-\mathrm{j}}$

(2) $)^{a} \Delta \mathrm{X}_{\mathrm{t}}=\alpha+\beta \mathrm{X}_{\mathrm{t}-\mathrm{1}}+\sum_{\mathrm{j}=1}^{4} \delta_{\mathrm{j}} \Delta \mathrm{X}_{\mathrm{t}-\mathrm{j}}+\gamma \mathrm{t}$

\begin{tabular}{lcc}
\hline $\begin{array}{l}\text { Interest rate } \\
\text { variable used }\end{array}$ & $\begin{array}{c}\text { t-statistic on lag } \\
\text { variable, } \mathbf{x}_{\mathbf{t}-\mathbf{1}}\end{array}$ & $\begin{array}{c}\text { F-statistic on lag variable, } \\
\mathbf{x}_{\mathbf{t}-\mathbf{- 1}}, \text { and time, } \mathbf{t}\end{array}$ \\
\hline 3-month rate & $-3.45^{*}$ & $13.12^{*}$ \\
6-month rate & $-3.87^{*}$ & $16.11^{*}$ \\
1-year rate & $-3.76^{*}$ & $14.50^{*}$ \\
3-year rate & $-2.98^{*}$ & $7.67^{*}$ \\
\hline
\end{tabular}

*denotes significance at the 5 percent level.

The 5 percent critical value for the $t$-ratio is -2.88 .

The 5 percent critical value for the F-ratio is 6.34 .

aNote in model (2) that $t$ represents the time trend variable.

Some summary statistics are shown in Table 3 . Note that the mean values of the net discount rate, $k_{t}=\left(r_{t}-g_{t}\right) /\left(1+g_{t}\right)$. These mean values range from approximately zero to plus 2 percent.

Table 3

Summary Statistics for the Net Discount Ratios and Rates, 1964-1989

Net Discount Ratio: $(1+g) /(1+r)$

\begin{tabular}{lcc}
\hline Using the following Treasury Securities & Mean & Standard Deviation \\
\hline 3-month & 1.00 & 0.05 \\
6-month & 0.99 & 0.05 \\
1-year & 0.98 & 0.05 \\
3-year & 0.98 & 0.06 \\
\hline
\end{tabular}

Net Discount Rate: $k=(r-g) /(1+g)$

\begin{tabular}{lcc}
\hline Using the following Treasury Securities & Mean & Standard Deviation \\
\hline 3-month & -0.001 & 0.05 \\
6-month & 0.01 & 0.05 \\
1-year & 0.02 & 0.05 \\
3-year & 0.02 & 0.06 \\
\hline
\end{tabular}




\section{Conclusion}

This article has found that the growth rate in real wages is stationary, as Lambrinos (1985) concluded. The current results differ with Lambrinos' (1985), however, because the findings suggest that real interest rates are not stationary. The issue of individual stationarity of each of these series is really moot. Ultimately, the concern is whether the net discount ratio series is stationary. Since the stationarity of individual series does not guarantee stationarity of a non-linear transformation, such as $\left(1+\mathrm{g}_{\mathrm{t}}\right) /\left(1+\mathrm{r}_{\mathrm{t}}\right)$, this article's contribution is providing evidence suggesting that the net discount ratio is stationary. This finding is robust since it holds for at least four different Treasury securities: three month, six month, one year, and three year. Therefore, a real net discount ratio can be used confidently in forecasting the present value of expected earnings.

\section{REFERENCES}

$\rightarrow$ Anderson, Gary A. and David L. Roberts, 1989, Stability in the Present Value Assessment of Lost Earnings, Journal of Risk and Insurance, 56: 50-66.

$\rightarrow$ Becker, William E. and George C. Alter, 1987, The Probability of Life and

Workforce Status in the Calculation of Expected Earnings, Journal of Risk and Insurance, 54: 364-75.

Bell, Edward B. and Allan J. Taub, 1977, Additional Comment, Journal of Risk and Insurance, 54: 122-29.

$\rightarrow$ Bryan, William R. and Charles M. Linke, 1988, Estimating Present Value of Future Earnings: Experience with Dedicated Portfolios, Journal of Risk and Insurance, 55: 273-86.

$\rightarrow$ Carpenter, Michael D., David R. Lange, Donald S. Shannon and William Thomas Stevens, 1986, Methodologies of Valuing Lost Earnings: A Review, A Criticism, and A Recommendation, Journal of Risk and Insurance, 53: 104-18.

Edwards, N. Fayne, 1975, Selecting the Discount Rate in Personal Injury and Wrongful Death Cases, Journal of Risk and Insurance, 52: 342-45.

Engle, Robert F. and C.W.J. Granger, 1977, Co-Integration, and ErrorCorrection: Representation, Estimation and Testing, Econometrica, 55: 251-76.

$\rightarrow$ Franz, Wolfgang W., 1978, A Solution to Problems Arising from Inflation When Determining Damages, Journal of Risk and Insurance, 45: 323-33. Fuller, Wayne A., 1976, Introduction to Statistical Time Series, New York: Wiley.

Granger, Clive W.J., 1989, Forecasting in Business and Economics, Boston: Academic Press.

Hallman, Jeffrey J. and C.W.J. Granger, 1989, The Algebra of I(1), unpublished manuscript.

$\rightarrow$ Harris, William G., 1983, Inflation Risk as Determinant of the Discount Rate of Tort Settlements, Journal of Risk and Insurance, 50: 265-80. 
Hickman, Edgar P., 1977, Further Comment, Journal of Risk and Insurance, 54: $129-32$.

$\rightarrow$ Hosek, William R., 1982, Problems in the Use of Historical Data in Estimating Economic Loss in Wrongful Death and Injury Cases, Journal of Risk and Insurance, 49: 300-08.

$\rightarrow$ Jones, David D., 1985, Inflation Rates Implicit in Discounting Personal Injury Economic Losses, Journal of Risk and Insurance, 52: 144-50.

$\rightarrow$ Laber, Gene, 1977, The Use of Inflation Factors in Determining Settlements in Personal Injury and Death Suits: Comment, Journal of Risk and Insurance, 44: 469-73.

$\rightarrow$ Lambrinos, James, 1985, On the Use of Historical Data in the Estimation of Economic Losses, Journal of Risk and Insurance, 52: 464-76.

$\rightarrow$ Lambrinos, James and Oskar R. Harmon, 1989, An Empirical Evaluation of Two Methods For Estimating Economic Damages, Journal of Risk and Insurance, 56: 733-39.

$\rightarrow$ Lane, Julia and Dennis Glennon, 1985, The Estimation of Age/Earnings

Profiles in Wrongful Death and Injury Cases, Journal of Risk and Insurance, 52: 686-95.

Leuthold, Steven C., 1981, Interest Rates, Inflation and Deflation, Financial Analysts Journal, Jan-Feb.: 28-40.

$\rightarrow$ Nieswiadomy, Michael L. and Daniel J. Slottje, 1988, Estimating Lost Future Earnings Using the New Worklife Tables: A Comment, Journal of Risk and Insurance, 55: 539-44.

Nieswiadomy, Michael L. and Eugene Silberberg, 1988, Calculating Changes in Worklife Expectancies and Lost Earnings in Personal Injury Cases, Journal of Risk and Insurance, 55: 492-98.

Pagan, Adrian R. and M.R. Wickens, 1989, A Survey of Recent Econometric Methods, The Economic Journal, 99:962-1025.

Schilling, Don, 1985, Estimating Present Value of Future income losses: An Historical Simulation 1900-1982, Journal of Risk and Insurance, 52: 100-16.

$\rightarrow$ Smith, Franklin C., 1976, The Use of Inflation Factors in Determining Settlements in Personal Injury and Death Suits, Journal of Risk and Insurance, 43: 369-76.

$\rightarrow$ Stock, James H. and Mark W. Watson, 1988, Variable Trends in Economic Time Series, The Journal of Economic Perspectives, 2: 147-74.

Vernon, Jack, 1985, Discounting After Tax Earnings with After Tax Yields in Torts Settlements, Journal of Risk and Insurance, 2: 696-703. 